\title{
BUDAYA ORGANISASI DAN DISIPLIN KERJA SERTA PENGARUHNYA TERHADAP KINERJA KARYAWAN
}

\author{
Munawir Nasir ${ }^{1}$, Rezky Ratnasari Taufan ${ }^{2}$, M Fadhil $^{3}$, Muh. Haerdiansyah Syahnur ${ }^{4}$ \\ Manajemen dan Bisnis, Universitas Muslim Indonesia, Makassar \\ e-mail: munawirnasir.hamzah@umi.ac.id ${ }^{1}$,reskyratnasari@umi.ac.id ${ }^{2}$, muhammadfadhil@umi.ac.id ${ }^{3}$ \\ haerdiansyah@umi.ac.id ${ }^{4}$
}

\begin{abstract}
Abstrak
Penelitian ini bertujuan untuk mengetahui pengaruh budaya organisasi dan disiplin kerja terhadap kinerja karyawan. Penelitian dilakukan pada salah satu Koperasi Simpan Pinjam (KSP) yang berada pada kabupaten Pinrang, Sulawesi Selatan. Metode penelitian yang digunakan adalah metode kuantitatif dengan pengujian statistik menggunakan aplikasi SPSS v 25. Metode sampel jenuh digunakan pada penelitian ini, yakni semua anggota populasi yang berjumlah 20 orang karyawan. Hasil penelitian menunjukkan bahwa budaya organisasi tidak berpengaruh terhadap kinerja karyawan, hal ini ditunjukkan dengan nilai $t_{\text {hitung }}(1,771)$ yang lebih kecil dari nilai $t_{\text {tabel }}(2,109)$. Sedangkan disiplin kerja berpengaruh positif dan signifikan terhadap kinerja, yang menunjukkan dengan nilai $t_{\text {hitung }}(2,973)$ yang lebih besar dari nilai $t_{\text {tabel. }}$. Pada uji serempak, diperoleh bahwa variabel budaya organisasi dan disiplin kerja berpengaruh secara bersamasama terhadap kinerja karyawan. Nilai $\mathrm{R}^{2}$ pada penelitian ini adalah 0,701 yang berarti bahwa variabel budaya organisasi dan variabel disiplin kerja secara bersama-sama berpengaruh terhadap kinerja karyawan sebesar 70,1\% sedangkan sisanya senilai $29,9 \%$ dipengaruhi oleh variabel di luar persamaan regresi ini atau variabel yang tidak diteliti.
\end{abstract}

Kata kunci: budaya organisasi, disiplin kerja, kinerja karyawan.

\begin{abstract}
.
The purpose of this study is to determine the relationship between organizational culture and work discipline on employee performance. The research was conducted at one of the credit unions in South Sulawesi's district of Pinrang. The research design is quantitative, with statistical analysis performed using the SPSS $v 25$ application. The saturation sampling technique was used in this study, which included all members of the population, which amounted to 20 employees. The findings indicate that organizational culture has no effect on employee performance, as evidenced by the fact that the $t_{\text {value }}$ (1.771) is less than the $t_{\text {table }}$ which (2.109). While work discipline has a positive and significant effect on performance, which shows that the $t_{\text {value }}(2.973)$ is bigger than the $t_{\text {table. }}$. Simultaneous testing revealed that organizational culture and work discipline both have an effect on employee performance. The $R^{2}$ value in this study was 0.701, indicating that organizational culture and work discipline variables have a combined effect on employee performance, with the remaining 70.1 percent, or 29.9 percent, influenced by variables not included in the regression equation or variables researched.
\end{abstract}

Keywords: organizational culture, job discipline, employee performance.

\section{PENDAHULUAN}

Keberhasilan suatu perusahaan sangat dipengaruhi oleh sumber daya manusia yang dimilikinya. Semakin baik kinerja seorang karyawan maka semakin meningkat produktifitas perusahaan tersebut, semakin buruk kinerja seorang karyawan maka produktifitas perusahaan akan menurun. (Moehiriono, 2009) keberhasilan kinerja pada suatu organisasi sangat bergantung pada individu yang berada pada organisasi tersebut meskipun berasal dari berbagai latar belakang budaya yang berbeda. Penilaian terhadap kinerja merupakan hasil kerja yang diperoleh dari setiap karyawan berdasarkan lingkup tanggung jawabnya, sehingga pencapaian kinerja suatu organisasi dapat dilihat dari bagaimana individu karyawan tersebut dalam menyelesaikan tanggung jawab yang diembannya (Rivai, 2009). Koperasi Simpan Pinjam-Syariah Wira Mandiri (KSP 
SWM) sadar bahwa dalam pencapaian tujuan perusahaan dibutuhkan nilai-nilai dan keyakinan untuk membantu karyawan dalam bertindak, berpikir dan menyelesaikan suatu permasalahan dalam organisasi. Selain itu, sistem nilai yang kuat dapat menumbuhkan rasa memiliki dan meningkatkan semangat kerja, hal tersebut berdampak pada meningkatnya kinerja karyawan.

Organisasi tidak akan berkembang menjadi organisasi yang maju tanpa memperkokoh fondasi budayanya, setelah budaya kuat maka akan berpengaruh besar terhadap strategi yang dijalankan untuk mencapai tujuan yang telah ditetapkan. Berdasarkan (Muis \& Fahmi, 2018) bahwa ada pengaruh positif dan signifikan antara budaya organisasi terhadap kinerja, yang mana mendukung teori dari (Sutrisno, 2010) agar karyawan didorong untuk berperilaku positif, dedikatif dan produktif, maka budaya organisasi harus benar-benar dikelola sebagai alat manajemen yang efektif. Nilai-nilai pada budaya organisasi itu tidak tampak, tetapi dapat menjadi kekuatan yang mendorong perilaku individu karyawan dalam menghasilkan efektivitas kinerja. Selain itu, budaya yang berada pada organisasi mempunyai tujuan agar SDM yang ada pada organisasi tersebut mau mengubah sikap yang berdampak pada meningkatnya kinerja dalam hal menghadapi berbagai tantangan dimasa yang akan datang.

Berdasarkan (Meutia et al., 2019) bahwa budaya organisasi berpengaruh secara positif terhadap kinerja karyawan, hal ini mengkonfirmasi beberapa faktor dari budaya organisasi yang merupakan sekumpulan nilai dan diyakini bersama dapat menjadi pengikat organisasi dengan karyawan. Hal ini dapat memotivasi karyawan untuk memberikan daya serta upayanya dengan maksimal sehingga kinerja karyawan dapat menjadi maksimal. Namun hal lain dibuktikan oleh (Junaidi \& Susanti, 2019) bahwa tidak terdapat pengaruh antara variabel budaya kerja dengan kinerja pegawai dimana kinerja pegawai pada salah satu UPT Dinas Pendidikan Provinsi Sumatera Barat dapat disebabkan beberapa faktor seperti : perhatian kerincian, orientasi hasil, orientasi orang, orientasi tim dan keagresifan.

Disisi lain bila disiplin kerja tidak ditegakkan, maka kemungkinan tujuan yang telah ditetapkan tidak dapat dicapai secara efektif dan efisien. berdasarkan (Saifuddin, 2011), meskipun suatu perusahaan telah memerhatikan pendidikan, keahlian dan teknologi secara maksimal namun jika tidak disertai dengan semangat dan disiplin kerja karyawan, maka hal tersebut tidak akan menghasilkan produk yang maksimal karena yang bersangkutan tidak dapat memanfaatkannya secara teratur dan tidak memiliki kesungguhan dalam disiplin kerja yang tinggi. (Rosmayati \& Maulana, 2020) mengungkapkan bahwa variabel disiplin kerja paling berpengaruh terhadap kinerja berdasarkan hasil kajian dengan menggunakan metode analisis jalur. Penelitian yang dilakukan pada Pengurus Primer Koperasi TNI di Cimahi, Jawa Barat mengungkapkan bahwa disiplin kerja para pengurus dapat ditingkatkan dengan cara mewajibkan hadir setiap hari melalui apel pagi.

Pada (Rivai, 2009), Fred Luthan berpendapat bahwa disiplin adalah operasi manajemen yang mendorong kepatuhan terhadap standar pekerjaan. Dengan kata lain, jika menginginkan efisiensi kinerja manajemen yang tinggi, maka dapat dilakukan dengan meningkatkan disiplin kerja para karyawan, sebaliknya pun demikian. Hal ini dapat dilihat sebagai bentuk pelatihan bagi manajer dalam penerapan aturan organisasi. Berdasarkan (Yanti et al., 2015) pada penelitian terkait disiplin kerja pada CV Kopari 
Puri Kencana Taxi Semarang, menyatakan bahwa ada pengaruh positif dan signifikan dari variable ini terhadap kinerja karyawan.

\section{KAJIAN TEORITIS \\ Budaya Organisasi}

Budaya menurut (Luthans, 2012) didefinisikan sebagai pengetahuan yang diperoleh untuk menginterpresentasikan pengalaman dan menghasilkan perilaku sosial. Menurut (Fey et al., 2003) budaya organisasi dapat diartikan sebagai nilai, keyakinan, dan prinsip dasar yang menjadi landasan pada sistem dan praktik-praktik manajemen serta didorong dari perilaku yang meningkatkan dan menguatkan prinsip-prinsip tersebut. Berdasarkan (Sutrisno, 2010) budaya organisasi merupakan perangkat sistem nilai-nilai (value), keyakinan (beliefs) atau norma-norma yang ditetapkan dan disepakati yang wajib diikuti oleh para anggota suatu organisasi, dijadikan sebagai pedoman dalam berperilaku dan pemecahan suatu masalah pada organisasi tersebut. Jadi, jika diambil kesimpulan dari beberapa teori di atas, dapat dipahami bahwa budaya organisasi adalah suatu keyakinan yang disepakati dan diikuti oleh seluruh anggota organisasi yang didalamnya. Budaya organisasi mencakup nilai, norma, dan aturan yang menjadi pedoman dalam mencapai tujuan organisasi dan sebagai dasar mengurai persoalan ataupun masalah-masalah yang dihadapi organisasi. Karakter budaya dalam organisasi menurut (Winardi et al., 2012) adalah: (1) Inovasi dan keberanian mengambil risiko (innovation and risk taking); (2) Perhatian pada hal-hal yang rinci (attention to detail); (3) Orientasi pada hasil (outcome orientation); (4) Orientasi orang (people orientation); (5) Orientasi tim (team orientation); (6) Sikap keagresifan (aggressiveness); dan (7) Adanya stabilitas (stability).

\section{Disiplin Kerja}

Berdasarkan (Nuraini, 2013) bahwa disiplin kerja adalah sikap menghormati, menghargai, patuh dan taat terhadap semua peraturan yang ada baik peraturan tertulis maupun tidak tertulis, serta kesiapan dalam menjalankan dan siap untuk menerima setiap sanksi atas pelanggaran tugas dan wewenang dari apa yang dibebankan kepadanya. Sedangkan menurut (Sedarmayanti, 2010) disiplin merupakan kunci terwujudnya tujuan yang maksimal dan merupakan salah satu fungsi dari manajemen sumber daya manusia. Kedisiplinan dalam bekerja merupakan kesadaran serta kesediaan seorang individu dalam menaati peraturan perusahaan dan norma-norma sosial yang berlaku. (Hasibuan, 2013) disiplin yang baik mencerminkan besarnya tanggung jawab seseorang dari apapun tugas-tugas yang diamanahkan kepadanya. Disiplin kerja dapat mendorong gairah dalam bekerja, semangat, sehingga terwujudnya tujuan organisasi secara maksimal. Dari teori-teori tersebut, jika diambil kesimpulan maka disiplin kerja merupakan suatu sikap atau perilaku menghormati, menghargai, patuh, dan taat pada peraturan-peraturan yang berlaku demi menjaga kelancaran produktifitas organisasi. Berdasarkan (Harlie, 2012) indikator dari disiplin kerja adalah sebagai berikut: (1) Hadir tepat waktu; (2) Mengutamakan presentase kehadiran; (3) Taat pada ketentuan jam kerja; (4) Fokus pada jam kerja yang efisien dan efektif; (5) Adanya keterampilan kerja pada bidang tugas yang diberikan padanya; (6) Semangat kerja tinggi; (7) Bersikap baik; dan (8) Kreatif dan inovatif dalam berkerja. 


\section{Kinerja Karyawan}

Kinerja pegawai didefinisikan oleh (Sinambela, 2012) sebagai kemampuan pegawai dalam melakukan sesuatu keahlian tertentu. Menurut (Rivai, 2009) kinerja adalah adalah hasil keseluruhan seseorang pada jangka ataupun periode tertentu dalam melaksanakan suatu tugas, hal ini mengartikan kinerja seperti standar hasil kerja, target atau sasaran ataupun kriteria yang telah ditentukan terlebih dahulu yang telah disepakati bersama. Berdasarkan (Sedarmayanti, 2010) kinerja merupakan terjemahan dari performance yang berarti hasil dari pekerjaan seseorang, dimana hal ini merupakan sebuah proses manajemen atau suatu organisasi secara keseluruh, yang mana hasil kerja tersebut dapat ditunjukkan secara konkrit dan dapat diukur atau dibandingkan dengan standar yang telah ditentukan oleh organisasi. Dari beberapa teori tersebut, dapat disimpulkan bahwa kinerja adalah kemampuan karyawan dalam menyelesaikan suatu pekerjaan yang dibebankan olehnya pada periode tertentu yang dapat ditunjukkan secara nyata serta dapat diukur berdasarkan ketentuan yang ditetapkan oranisasi. Pada penelitian ini indikator dari kinerja (Indraswari, 2011), (Bintari \& Asyik, 2018) dimana adalah: (1) Pelaksanaan tugas dilakukan secara ekonomis, efektif dan efisien, (2) Pencapaian tujuan organisasi, (3) Pemberian pelayanan berkualitas.

\section{Hubungan Antar Variabel}

Penelitian (Tintami et al., 2013) mengungkap hubungan antara Budaya organisasi dan disiplin kerja, dimana budaya organisasi baik maka disiplin kerja juga akan meningkat, begitu pula sebaliknya. Hubungan antara budaya organisasi dan disiplin kerja sesuai dengan penelitian yang diungkapkan oleh (Agustin et al., 2015) bahwa budaya organisasi dan disiplin kerja secara parsial maupun simultan mempengaruhi kinerja karyawan bagian produksi PT. Nyonya Meneer Semarang. Penelitian (Trang, 2013) menyatakan gaya kepemimpinan dan budaya organisasi berpengaruh positif dan signifikan terhadap kinerja karyawan. Sedangkan, secara parsial gaya kepemimpinan berpengaruh terhadap kinerja karyawan namun tidak signifikan, dan budaya organisasi berpengaruh positif dan signifikan terhadap kinerja karyawan. Berdasarkan penelitian (Sari, 2017) bahwa secara parsial budaya organisasi berpengaruh positif dan signifikan terhadap kinerja karyawan, disiplin kerja berpengaruh positif dan signifikan terhadap kinerja karyawan, dan secara simultan budaya organisasi dan disiplin kerja berpengaruh positif dan signifikan terhadap kinerja karyawan.

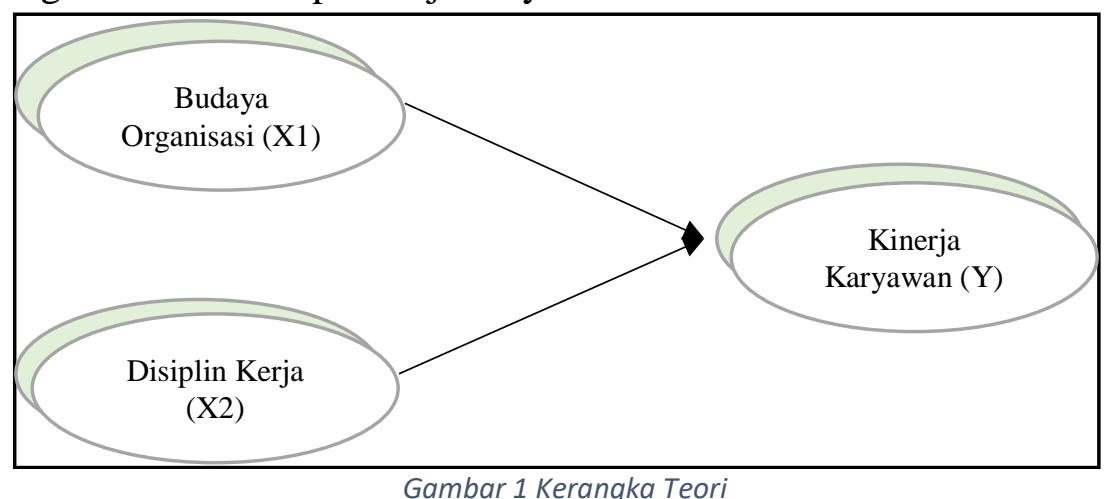

Sehingga dari hubungan antar variabel tersebut dibangun Hipotesis, bahwa : H1 : budaya organisasi berpengaruh secara positif dan signifikan terhadap kinerja karyawan 
pada KSP SWM, Pinrang Sulawesi Selatan. H2 : disiplin kerja berpengaruh secara positif dan signifikan terhadap kinerja karyawan pada KSP SWM, Pinrang Sulawesi Selatan.

\section{METODE PENELITIAN}

Kriteria Sampel

Pendekatan yang digunakan dalam penelitian ini adalah pendekatan kuantitatif karena data yang disajikan berhubungan dengan angka (kuantitatif) dan analisis yang digunakan adalah analisis statistik. Mendefinisikan populasi secara akurat sangat penting dalam penelitian yang melibatkan ramalan tentang bagaimana populasi tersebut akan memberikan statementnya terhadap suatu peristiwa. Untuk menentukan besarnya sampel apabila subjek kurang dari 100, lebih baik diambil semua sehingga penelitiannya penelitian populasi. Jika subjekya lebih besar dapat diambil antara 2025\%. Karena jumlah populasi (karyawan) relatif terbatas maka metode yang dipakai adalah metode sampling jenuh, yakni seluruh karyawan koperasi dijadikan responden, (Sugiyono, 2014). Pada penelitian ini menggunakan seluruh julmah karyawan KSP SWM yang berjumlah 20 orang.

Kuesioner disusun berdasarkan variabel dan indikator yang disadur dari penelitian terdahulu diantaranya adalah Budaya Organisasi (Umam, 2018), Disiplin Kerja (Hasibuan, 2013), dan Kinerja (Rivai, 2009). Digunakan lima skala Likert (Malhotra, 2019) dalam memberikan skala jawaban dari 1-Sangat Tidak Sesuai; 2-Tidak Sesuai; 3Cukup; 4-Sesuai; dan 5-Sangat Sesuai. Aplikasi analisis data yang digunakan pada penelitian ini adalah software SPSS v25.00.

\section{Metode Analisis Data}

Konseptualisasi mencoba untuk memvisualisasi hubungan sebab akibat antara masalah yang melatarbelakangi penelitian yang dilakukan agara dapat dipahami secara detail. Penelitian ini bertujuan untuk menunjukkan hubungan antara Budaya Organisasi (X1), Disiplin Kerja (X2) terhadap Kinerja Karyawan (Y). Data kuantitatif yang digunakan diperoleh dalam bentuk angka-angka yang dapat dihitung, yang diperoleh dari perhitungan jawaban-jawaban responden atau kuesioner, yang berkaitan dengan masalah yang diteliti. Analisis data yang digunakan dalam penelitian ini adalah analisis regresi linier berganda dimana sebelumnya data telah lolos dari uji validitas \& reliabilitas, uji asumsi klasik yang menggunakan uji normalitas, uji multikolinieritas, dan uji heteroskedastisitas. Persamaan regresi linier berganda (Sugiyono, 2014) adalah sebagai berikut:

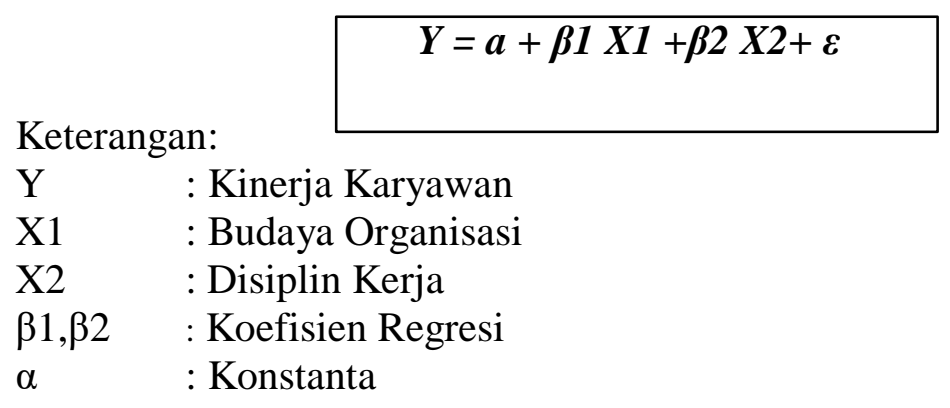

Untuk menguji sejauh mana pengaruh Budaya Organisasi dan Disiplin Kerja terhadap Kinerja Karyawan, maka digunakan : (1) Uji F (uji simultan) : digunakan 
untuk mengetahui tingkat signifikan dari pengaruh variable independent secara serempak terhadap variabel dependent. Uji dilaksanan dengan langkah membandingkan nilai $\mathrm{F}$ hitung dengan $\mathrm{F}$ tabel dengan kriterianya : (1.1) $\mathrm{H} 0$ diterima jika $\mathrm{F}$ hitung $<\mathrm{F}$ tabel atau nilai sig. $>0,05$ dimana variabel independent $(\mathrm{X})$ secara bersama-sama tidak memiliki pengaruh signifikan terhadap variabel dependent (Y); (1.2) H0 ditolak (H1 diterima) jika $\mathrm{F}$ hitung $>\mathrm{F}$ tabel atau nilai sig. $<0,05$ dimana variabel independent $(\mathrm{X})$ secara bersama-sama memiliki pengaruh signifikan terhadap variabel dependent (Y). (2) Uji T (uji parsial) : digunakan untuk menguji tingkat signifikan dari pengaruh variable independent secara parsial terhadap variabel dependent. Uji dilaksanakan dengan langkah membandingkan nilai Thitung dengan Ttabel kriteria (2.1). H0 diterima jika T hitung $<\mathrm{T}$ tabel atau nilai sig. $>0,05$ dimana variabel independent $(\mathrm{X})$ secara individual tidak memiliki pengaruh signifikan terhadap variabel dependent (Y); (2.2). H0 ditolak (H1 diterima) jika Thitung > Ttabel atau nilai sig. < 0,05 dimana variabel independent (X) secara individual memiliki pengaruh signifikan terhadap variabel dependent (Y).

\section{HASIL DAN PEMBAHASAN Pengujian Sampel}

Penelitian ini menggunakan metode regresi linier berganda dengan bantuan program SPSS (Statistical Product Service Solution) versi 25.00 dimana semua variabel independen digunakan untuk menjelaskan variabel dependen. Pada penelitian ini digunakan suatu model analisis regresi berganda, untuk mengetahui besarnya pengaruh dari semua variabel independen secara bersama-sama terhadap variabel dependen. Langkah-langkah pengujian seperti dijelaskan pada bagian sebelumnya.

\section{Tabel 1 Uji Validitas dan Reliabilitas Instrumen}

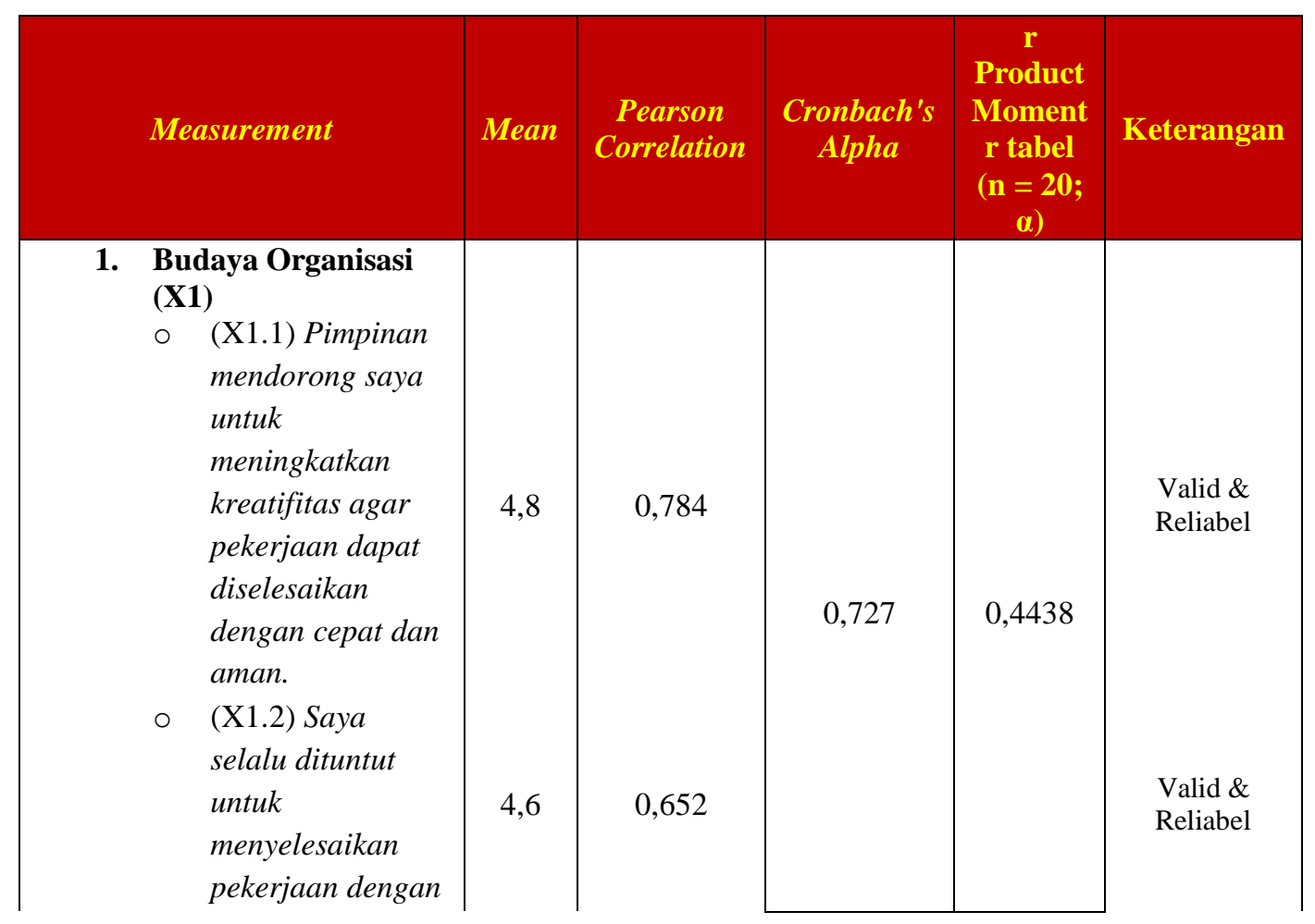


Hal. 71 - 83

e-ISSN : 2621-4377 \& p-ISSN : 1829-8524

Hbmepage: https//e-jurnal.stienobel-indonesiaacid/indexphp/akmen

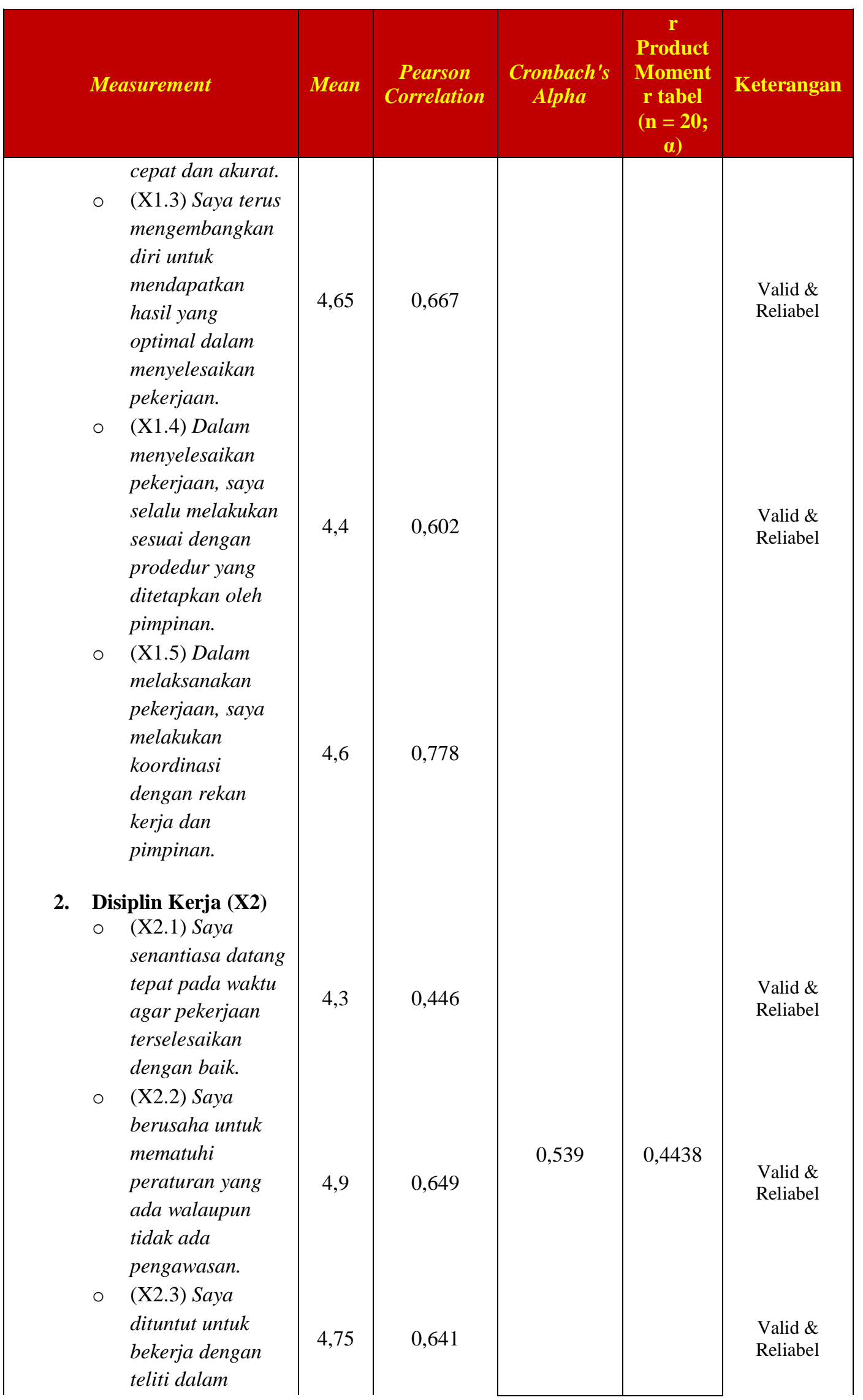


Hal. 71 - 83

e-ISSN : 2621-4377 \& p-ISSN : 1829-8524

Hbmepage: https//e-jurnal.stienobel-indonesiaacid/indexphp/akmen

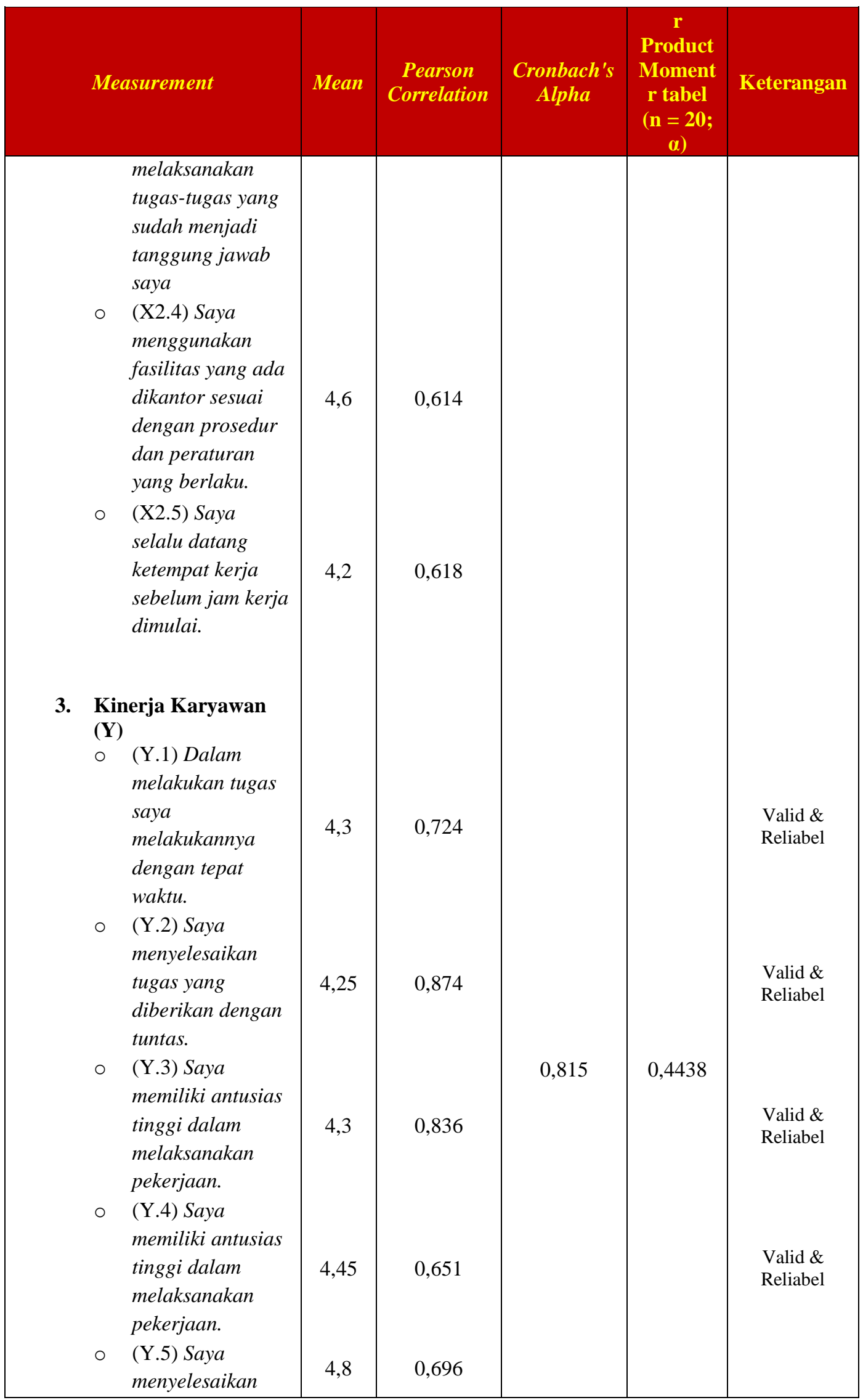


Hal. 71 - 83

e-ISSN : 2621-4377 \& p-ISSN : 1829-8524

Hbmepage: https//e-jurnal.stiendbel-indonesiaacid/indexphp/akmen

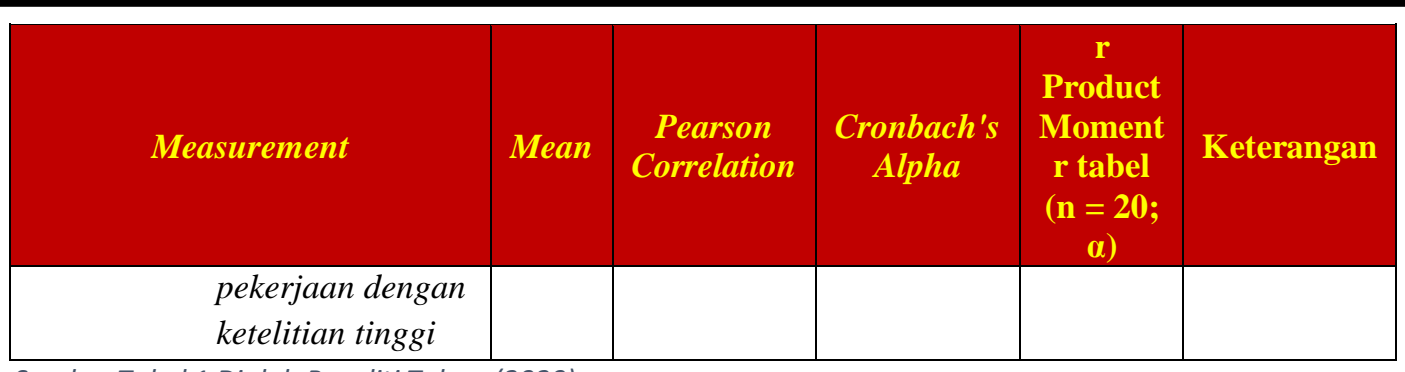

Sumber Tabel 1 Diolah Peneliti Tahun (2020)

Tahapan analisa diatas yaitu uji validitas instrument dari variabel keunggulan bersaing diperoleh nilai Corrected Item Total Correlation ( $\mathrm{r}$ hitung) antara 0,446 0,874 atau $\mathrm{r}$ hitung > $\mathrm{r}$ tabel 0,44438 ; dan Uji reliabilitas instrumen dari variabel keunggulan bersaing diperoleh nilai Cronbach Alpha (r hitung) antara 0,539 - 0,815 atau $\mathrm{r}$ hitung $>\mathrm{r}$ tabel 0,4438 , yang berarti setiap butir pernyataan dari variabel keunggulan bersaing yang digunakan dalam penelitian ini adalah valid dan reliabel (handal); tahap uji berikutnya ialah Uji normalitas, Uji Multikolinieritas, dimana regresi dikatakan baik jika suatu regresi tidak memiliki multikolinearitas didalamnya sehingga tidak ada gangguan yang diharapkan akan terjadi pada regresi tersebut. Keberadaan multikolinearitas dapat dilihat melalui nilai VIF (Variance Inflation Factors) atau nilai toleransinya, yakni apabila nilai VIF > 10 atau secara kebalikannya dengan melihat nilai toleransinya $<0,01$. Dan uji Heterokedastisitas.

Tabel 2 Tabel Pengujian Statistik

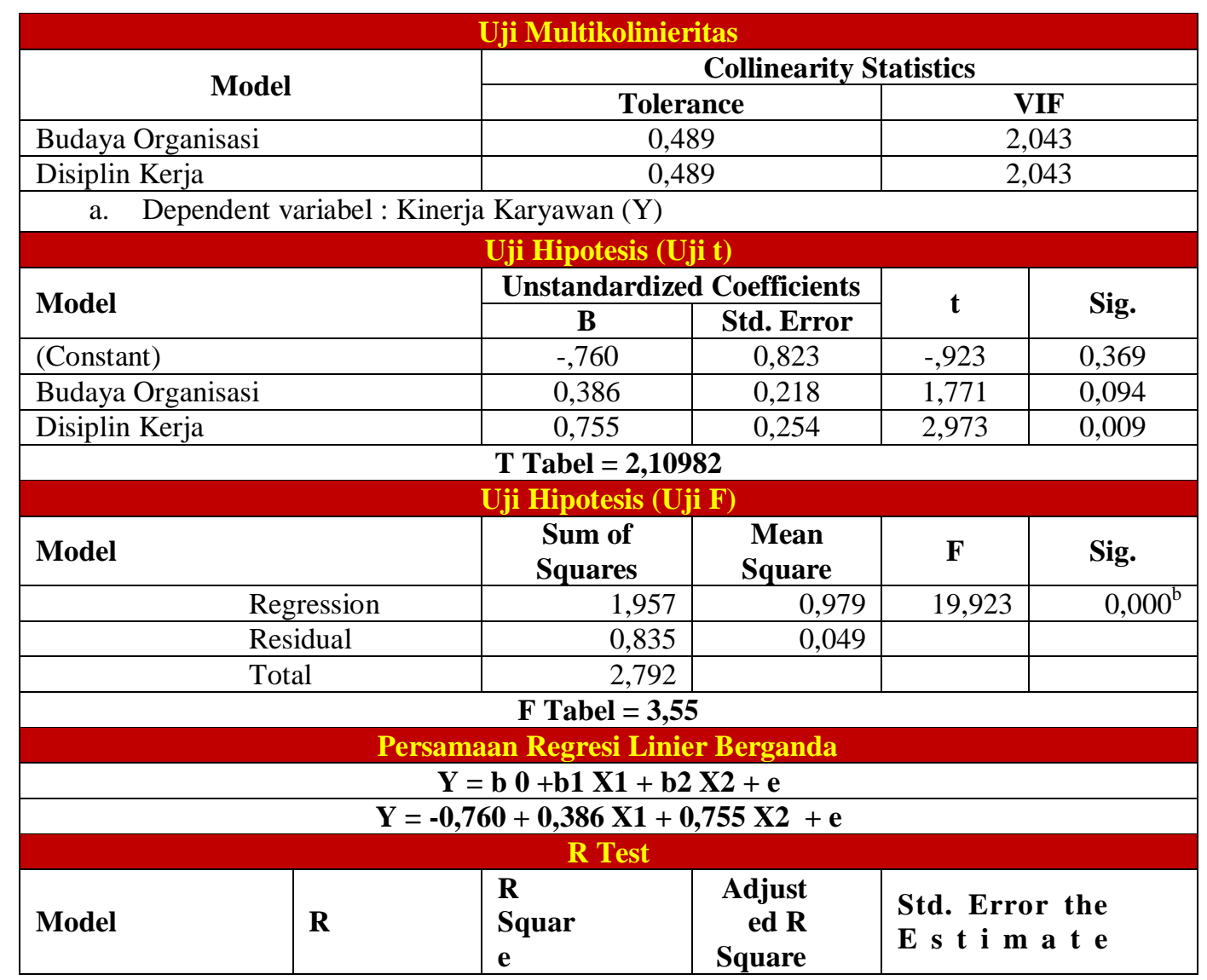


Hasil pengujian statistik pada tabel 2 diatas, menunjukkan pengaruh variabel budaya dan disiplin kerja terhadap kinerja karyawan pada KSP SWM Kab. Pinrang, Sulawesi Selatan. Dapat diketahui pada variabel Budaya Organisasi dari nilai t- hitung < t- tabel yakni $1,771<2,10982 *$ (yang diperoleh dari df $2=20$; sig. $=0,05)$ dengan nilai signifikansi 0,094 > 0,05. Hal ini berarti bahwa Budaya Organisasi tidak berpengaruh terhadap kinerja karyawan pada KSP SWM Kab. Pinrang Sulawesi Selatan. Pada variabel Disiplin Kerja, nilai t- hitung > t- tabel yakni 2,973>2,109 dengan nilai signifikansi $0,009<0,05$. Hal ini menyatakan bahwa Disiplin Kerja berpengaruh positif dan signifikan terhadap kinerja karyawan pada KSP SWM Kab. Pinrang Sulawesi Selatan. Selanjutnya pada uji F diketahui nilai F Hitung > F tabel yakni 19,923 > 3,55, hal ini menyatakan bahwa variabel budaya organisasi dan disiplin kerja berpengaruh secara bersama-sama terhadap kinerja karyawan. Dapat dijelaskan bahwa besarnya koefisien determinasi $\left(\mathrm{R}^{2}\right)$ adalah 0,701 dimana angka koefisien determinasi ini menyatakan bahwa besarnya pengaruh variabel budaya organisasi dan disiplin kerja secara simultan berpengaruh terhadap kinerja karyawan pada KSP SWM Kab. Pinrang, Sulawesi. Sedangkan sisanya 29,9\% dijelaskan oleh variabel lain yang tidak digunakan pada penelitian ini.

\section{PEMBAHASAN}

Hasil uji signifikansi menunjukkan nilai t-hitung sebesar 1,771. Karena nilai $\mathrm{T}$ hitung 1,771 < T tabel 2.109 maka sesuai dengan dasar pengambilan keputusan dalam uji $\mathrm{T}$ dapat disimpulkan bahwa hipotesis pertama ditolak. Artinya tidak ada pengaruh $\mathrm{X}_{1}$ (Budaya Organisasi) terhadap Y (Kinerja Karyawan). Hal ini menunjukkan bahwa hipotesis 1 yang menyatakan bahwa budaya organisasi berpengaruh positif dan signifikan terhadap kinerja karyawan tidak terbukti. Berdasarkan hasil wawancara peneliti ke salah satu pimpinan perusahaan faktor utama yang membuat budaya organisasi tidak berpengaruh pada kinerja karyawan adalah dalam melaksanakan pekerjaan karyawan melakukannya sebagian besar secara individu baik dalam pemberian pinjaman, pengontrolan kreditur, dan pengolahan data kreditur. Yang dengan kata lain dalam melakukan pekerjaan sangat kurang dari segi orientasi tim yang merupakan salah satu indikator budaya organisasi,

Padahal budaya organisasi merupakan salah satu hal yang penting dalam meningkatkan kinerja karyawan karena budaya organisasi akan mempunyai dampak positif bagi perilaku karyawan dalam melaksanakan tugas dan meningkatkan kinerja karyawan, budaya organisasi juga berfungsi sebagai media yang menyatukan organisasi dan dapat mengendalikan serta membentuk sikap serta perilaku para karyawan. Seperti teori yang sudah ada yang menyatakan bahwa budaya organisasi berfungsi sebagai inti dari organisasi karena disana terdapat filosofi, misi dan visi organisasi yang jika diinternalisasikan oleh semua anggota organisasi akan menjadi kekuatan bagi organisasi tersebut untuk bersaing atau berkompetensi. Penelitian ini tidak sejalan dengan penelitian terdahulu yang dilakukan oleh (Taurisa \& Ratnawati, 2012) yang menyatakan budaya organisasi berpengaruh positif dan signifikan terhadap kinerja karyawan. 
Hasil uji pada variabel disiplin kerja menunjukkan nilai t-hitung sebesar 2,973 dan karena nilai T hitung 2,973 > T tabel 2.109 maka sesuai dengan dasar pengambilan keputusan dalam uji $\mathrm{T}$ dapat disimpulkan bahwa hipotesis kedua diterima. Artinya ada pengaruh $\mathrm{X}_{2}$ (disiplin kerja) terhadap $\mathrm{Y}$ (kinerja karyawan). Hal ini menunjukkan bahwa semakin tinggi tingkat displin kerja karyawan maka akan diikuti dengan meningkatnya kinerja karyawan dalam melakukan pekerjaan. Salah satu faktor yang meningkatkan kinerja karyawan adalah disiplin dalam bekerja, apabila karyawan menerapkan disiplin kerja meliputi menaati aturan-aturan perusahaan maka akan memudahkan untuk menyelesaikan tugas yang telah di berikan. Hal ini sejalan dengan teori yang sudah ada bahwa Menurut (Sedarmayanti, 2010) kedisplinan merupakan salah satu fungsi manajemen sumber daya manusia dan kunci terwujudnya tugas, tanpa kedisiplinan akan sulit mewujudkan tujuan yang maksimal. Hal ini tidak sejalan dengan penelitian terdahulu yang dilakukan oleh (Setiawan, 2013) bahwa disiplin kerja tidak mempengaruhi secara parsial maupun simultan terhadap kinerja karyawan.

Bahwa hasil penelitian pada pengujian serempak menunjukkan bahwa variabel budaya organisasi dan disiplin kerja secara simultan berpengaruh positif terhadap kinerja karyawan di Koperasi Simpan Pinjam Syariah Wira Mandiri. Berdasarkan output tabel ANOVA SPSS, diketahui nilai $F$ hitung adalah sebesar 19,923. Karena nilai $F$ hitung $19,923>\mathrm{F}$ tabel 3,55, maka sesuai dengan dasar pengambilan keputusan dalam uji $\mathrm{F}$ dapat disimpulkan bahwa hipotesis ketiga diterima atau dengan kata lain $\mathrm{X}_{1}$ (budaya organisasi) dan $\mathrm{X}_{2}$ (disiplin kerja) secara simultan berpengaruh terhadap $\mathrm{Y}$ (kinerja karyawan). Sehingga hipotesis ke-3 diterima dan dari hasil penelitian ini kita dapat melihat semakin meningkat budaya organisasi yang dibarengi dengan disiplin kerja maka semakin meningkat pula kinerja karyawan. Hal ini sejalan dengan penelitian terdahulu yang dilakukan oleh (Sari, 2017) bahwa secara simultan budaya organisasi dan disiplin kerja berpengaruh positif dan signifikan terhadap kinerja karyawan.

\section{KESIMPULAN DAN SARAN}

Setelah melakukan uji asumsi klasik dan uji statistik dengan metode regresi linier berganda mengenai pengaruh budaya organisasi dan disiplin kerja terhadap kinerja pada KSP SWM di Kabupaten Pinrang maka dapat disimpulkan bahwa: Hasil dari penelitian ini menunjukkan bahwa budaya organisasi tidak berpengaruh terhadap kinerja pada karyawan KSP SWM di Kab Pinrang, Sulawesi Selatan. Disiplin kerja berpengaruh positif dan signifikan terhadap kinerja karyawan dimana artinya jika disiplin kerja bertambah maka kinerja karyawan mengalami kenaikan.

Berdasarkan dari kesimpulan tersebut, maka diberikan beberapa saran sebagai berikut: Penelitian ini menunjukkan bahwa budaya organisasi tidak berpengaruh positif dan signifikan terhadap kinerja karyawan pada KSP SWM. Padahal sejatinya budaya organisasi merupakan nilai-nilai yang merekat pada organisasi dalam mewujudkan tujuannya, oleh karena itu peneliti menyarankan sebaiknya pimpinan mempertimbangkan pentingnya budaya organisasi dalam suatu perusahaan hal ini dikarenakan dengan tingginya tingkat kesadaran akan budaya organisasi maka akan mempermudah dalam penyelesaian masalah baik masalah internal maupun eksternal perusahaan. Penelitian ini menunjukkan bahwa disiplin kerja berpengaruh positif dan signifikan terhadap kinerja karyawan, karena itu peneliti menyarankan sebaiknya pimpinan agar senantiasa menjaga dan meningkatkan motivasi atau memberi pelatihan 
yang berkaitan dengan disiplin kerja demi meningkatkan kesadaran masing-masing karyawan untuk memahami pentingnya disiplin kerja sehinggah mempermudah mencapai tujuan perusahaan.

\section{DAFTAR REFERENSI}

Agustin, E. A., Hadi, S. P., \& Widiartanto, W. (2015). Pengaruh Budaya Organisasi dan Disiplin Kerja Terhadap Kinerja Karyawan (Studi Kasus Pada Karyawan Bagian Produksi PT. Nyonya Meneer Semarang). Jurnal Ilmu Administrasi Bisnis, 4(2), 243-253.

Bintari, D. A., \& Asyik, N. F. (2018). PENGARUH PERENCANAAN STRATEGI DAN KEPUASAN KERJA TERHADAP KINERJA PT SIER SURABAYA. Jurnal Ilmu Dan Riset Akuntansi (JIRA), 7(4).

Fey, C. F., Denison, D. R., Fey, C. F., \& Denison, D. R. (2003). Organizational Culture and Effectiveness : Can American Theory Be Applied in Russia? Organizational Culture and Effectiveness: Can American Theory Be Applied in Russia? Organization Science, 14(6).

Harlie, M. (2012). Pengaruh Disiplin Kerja , Motivasi dan Pengembangan Karier terhadap Kinerja Pegawai Negeri Sipil pada Pemerintah Kabupaten Tabalong di Tanjung Kalimantan Selatan. 10, 860-867.

Hasibuan, M. S. P. (2013). Manajemen Sumber Daya Manusia (Tujuh Bela). Bumi Aksara.

Indraswari, M. (2011). PENGARUH BUDAYA ORGANISASI DAN MOTIVASI TERHADAP KEPUASAN KERJA DALAM MEMPENGARUHI KINERJA KARYAWAN KANTOR UNIT PT TELKOM REGIONAL IV SEMARANG [Universitas Dipanegara]. http://eprints.undip.ac.id/29903

Junaidi, R., \& Susanti, F. (2019). Pengaruh Gaya Kepemimpinan Dan Budaya Organisasi Terhadap Kinerja Pegawai Pada UPTD Baltekkomdik Dinas Pendidikan Provinsi Sumatera Barat. 1-13.

Luthans, F. (2012). Perilaku Organisasi. Andi.

Malhotra, N. K. (2019). Marketing Research: An Applied Orientation, 7th Edition. Pearson.

Meutia, K. I., Husada, C., Dan, O., Organisasi, K., Kinerja, T., \& Jurnal, K. (2019). Pengaruh budaya organisasi dan komitmen organisasi terhadap kinerja karyawan. Jurnal Riset Manajemen Dan Bisnis, 4(1), 119-126.

Moehiriono. (2009). Pengukuran Kinerja Berbasis Kompensasi. Ghalia Indonesia.

Muis, M. R., \& Fahmi, M. (2018). Pengaruh Budaya Organisasi Dan Komitmen Organisasi Terhadap Kinerja Karyawan. Jurnal Ekonomi \& Ekonomi Syariah, $1(1), 9-25$.

Nuraini. (2013). Manajemen Sumber Daya Manusia. Yayasan Aini Syam.

Rivai, V. (2009). Manajemen Sumber Daya Manusia Untuk Perusahaan: Dari Teori ke Praktek. PT Rajagrafindo Persada. 
Rosmayati, S., \& Maulana, A. (2020). PENGARUH KEPEMIMPINAN, DISIPLIN KERJA DAN PELATIHAN TERHADAP KINERJA PENGURUS PRIMER KOPERASI KARTIKA ARDAGUSSEMA PUSAT KODIKLAT TNI AD DI CIMAHI. JURNAL AL AMAR, 1(2), 114-132.

Sari, N. N. P. (2017). PENGARUH BUDAYA ORGANISASI DAN DISIPLIN KERJA TERHADAP KINERJA KARYAWAN Bagian Kantor Pada PT. PLN(Persero) Area Pekanbaru Rayon Kota Timur. JOM FISIP, 4(2), 1-15.

Sedarmayanti. (2010). Sumber Daya Manusia dan Produktivitas Kerja. CV Mandar Maju.

Setiawan, A. (2013). PENGARUH DISIPLIN KERJA DAN MOTIVASI TERHADAP KINERJA KARYAWAN PADA RUMAH SAKIT UMUM DAERAH KANJURUHAN MALANG. Jurnal Ilmu Manajemen, 1(4).

Sinambela, L. P. (2012). Kinerja Pegawai. Graha Ilmu.

Sugiyono. (2014). Metode Penelitian Kombinasi. CV Alfabeta.

Sutrisno, E. (2010). Manajemen Sumber Daya Manusia (Pertama). Prenada Media.

Syahnur, M. H., Soeharijanto, M., \& Tazlie, L. (2018). Analisis Customer Experience Dengan Importance Performance Analysis (IPA)-Suatu Studi Pada Pelanggan Telkom Indihome Regional III Bandung. Jurnal Manajemen Bisnis, 5(2), 1-12.

Syahnur, M. H., Basalamah, J., \& Gani, A. A. (2020). Customer Experience Factor Analysis Towards Customer Satisfaction Online Shopping. Jurnal Analisis Bisnis Ekonomi, 18(2), 83-94.

Taurisa, C. M., \& Ratnawati, I. (2012). ANALISIS PENGARUH BUDAYA ORGANISASI DAN KEPUASAN KERJA TERHADAP KOMITMEN ORGANISASIONAL DALAM MENINGKATKAN KINERJA KARYAWAN (Studi pada PT. Sido Muncul Kaligawe Semarang). Jurnal Bisnis Dan Ekonomi (JBE), 19(2), 170-187.

Tintami, L., Pradhanawati, A., \& N, H. S. (2013). Pengaruh Budaya Organisasi dan Gaya Kepemimpinan Transformasional terhadap Kinerja Karyawan Melalui Disiplin Kerja pada Karyawan harian SKT Megawon II PT. Djarum Kudus. Jurnal Ilmu Administrasi Bisnis, 1(1), 1-8.

Trang, D. S. (2013). GAYA KEPEMIMPINAN DAN BUDAYA ORGANISASI PENGARUHNYA TERHADAP KINERJA KARYAWAN (Studi pada Perwakilan BPKP Provinsi Sulawesi Utara). Jurnal EMBA, 1(3), 208-216.

Umam, K. (2018). Perilaku Organisasi (Edisi II). Pustaka Setia.

Winardi, J. J., Ma'ruf, \& Musnadi, S. (2012). Pengaruh Budaya Organisasi dan Motivasi terhadap Kinerja Karyawan dengan Komitmen organisasional sebagai Variabel Intervening (studi pada Karyawan Dinas Pengairan Provinsi Aceh). Jurnal Ilmu Manajemen Universitas Syiah Kuala, 1.

Yanti, Haryono, A. T., \& Minarsih, M. M. (2015). Pengaruh Kompensasi , Motivasi Kerja, Lingkungan kerja dan disiplin terhadap Kinerja Karyawan pada CV Koperasi Puri Kencana Taxi Semarang. Journal of Management, 1(1), 1-23. 